\title{
PENGEMBANGAN KEMAMPUAN KOMUNIKASI MATEMATIS DALAM PEMBELAJARAN MATEMATIKA DI SEKOLAH DASAR
}

\author{
Yeni Yuniarti ${ }^{1}$
}

\begin{abstract}
ABSTRAK
Rumusan kompetensi sikap, pengetahuan, dan keterampilan yang dipergunakan dalam kurikulum 2013 mengedepankan pada pentingnya kreativitas dan komunikasi. Sementara saat ini kecenderungan guru dalam pembelajaran yaitu mendominasi komunikasi kelas dengan menjelaskan konsep, menunjukkan contoh, dan membimbing pertanyaan serta jawaban. Guru tidak memberikan banyak kesempatan kepada siswa untuk mengomunikasikan pikiran, ide dan gagasan mereka. Guru yang ideal menolong siswanya untuk belajar dengan tidak mengutamakan jawaban tetapi bagaimana merefleksinya, karakterisasi, dan mendiskusikan masalah, serta bagaimana mereka berinisiatif sendiri, membentuk atau menemukan jawaban yang valid. Menjadi suatu hal penting yang harus dilakukan oleh guru untuk mencari cara-cara meningkatkan kemampuan komunikasi matematis siswa.
\end{abstract}

Kata kunci: Kurikulum 2013, Komunikasi matematis.

\section{A. PENDAHULUAN}

Matematika sebagai suatu alat untuk mengembangkan cara berpikir, sangat diperlukan baik untuk kehidupan sehari-hari maupun dalam menghadapi kemajuan Ilmu Pengetahuan dan Teknologi, oleh sebab itu kebutuhan untuk memahami matematika harus lebih ditekankan lagi sejak sekolah dasar bahkan usia taman kanak-kanak.

Secara fungsional dalam mempelajari matematika dimulai dengan kemampuan untuk memahami teks matematika, kemampuan untuk mengingat istilah matematika, prosedur dan teori, kemampuan menguasai alat matematika yang diperlukan, dan kemampuan menerapkannya untuk memecahkan masalah. Pengembangan kemampuan dalam mempelajari matematika tersebut, tentu saja dibutuhkan guru-guru professional yang kompeten yang mampu mengomunikasikan kepada siswa sehingga dapat menjawab pertanyaan dan masalah yang timbul baik dari matematika maupun dalam situasi nyata. Seperti dinyatakan dalam Permendiknas No. 16 tahun 2007, bahwa standar kompetensi guru SD/MI diantaranya adalah berkomunikasi secara efektif, empatik, dan santun dengan siswa dengan bahasa yang khas dalam interaksi pembelajaran yang terbangun secara siklikal dari (a) penyiapan kondisi psikologis siswa, (b) memberikan pertanyaan atau tugas sebagai undangan kepada siswa untuk merespons, (c) respons siswa, (d) reaksi guru terhadap respons siswa, dan seterusnya. Demikian juga diungkapkan bahwa seorang guru SD harus memiliki kompetensi professional salah satunya mampu menggunakan pengetahuan

1 Dosen Univerisitas Pendidikan Indonesia Kampus Cibiru 
konseptual, prosedural, dan keterkaitan keduanya dalam pemecahan masalah matematika, serta. penerapannya dalam kehidupan sehari-hari.

Seorang guru harus mengembangkan kemampuannya dalam pemecahan masalah, mengingat termasuk di dalam tugasnya nanti ketika menjadi guru adalah membimbing peserta didik belajar memecahkan masalah matematika. Mengajarkan bagaimana menyelesaikan masalah merupakan kegiatan guru untuk memberikan tantangan atau motivasi kepada para siswa agar mereka mampu memahami masalah tersebut, tertarik untuk memecahkannya, mampu menggunakan semua pengetahuannya untuk merumuskan strategi dalam memecahkan masalah tersebut, melaksanakan strategi, dan menilai apakah jawabannya benar. Berdasarkan hal tersebut seorang guru tentu saja tidak hanya dituntut untuk memiliki kemampuan pemecahan masalah untuk dirinya sendiri akan tetapi dia juga harus memiliki kemampuan komunikasi, seperti dikemukakan dalam NCTM Program Standards (2003) bahwa seorang calon guru matematika haruslah mampu mengomunikasikan pikiran matematisnya secara lisan dan tertulis kepada teman-temannya, para dosen, dan kepada yang lainnya.

Pada umumnya, dalam suatu pembelajaran matematika siswa memecahkan masalah yang disediakan oleh seorang guru atau buku dengan tujuan supaya siswa dapat mengerti dan menjawab soal yang diberikan oleh guru dengan benar. Akan tetapi dalam prosesnya siswa jarang sekali diberi kesempatan untuk mengungkapkan pertanyaan ataupun dimintai penjelasan asal mula mereka mendapatkan jawaban. Hal ini mengakibatkan siswa jarang sekali berkomunikasi dalam matematika. Menurut Suryadi (2008) bahwa cara tradisional mengajar yang umum digunakan dalam mengajar matematika di Indonesia, tidak memiliki banyak kesempatan untuk mengkomunikasikan ide-ide mereka. Guru cenderung mendominasi komunikasi kelas oleh menjelaskan konsep, menunjukkan contoh, dan membimbing pertanyaan dan jawaban atau diskusi.

Berdasarkan hal tersebut diatas tidak dapat dipungkiri kenyataan yang terjadi bahwa masih lemahnya kemampuan komunikasi matematis siswa bahkan mahasiswa sekalipun, seperti diungkapkan oleh Widjayanti dan Wahyudin (2010) bahwa kenyataan masih terdapat mahasiswa calon guru matematika lemah dalam komunikasi matematis, maka cara-cara meningkatkan kemampuan komunikasi matematis siswa menjadi penting untuk dilakukan.

Berdasarkan hal tersebut di atas kemampuan komunikasi dalam pembelajaran matematika perlu ditumbuhkembangkan dikalangan peserta didik, karena matematika tidak hanya sekedar alat bantu berfikir, alat untuk menemukan pola, menyelesaikan masalah atau mengambil kesimpulan tetapi matematika juga sebagai aktivitas sosial dalam pembelajaran matematika, matematika sebagai wahana interaksi antar peserta didik dan juga komunikasi antara guru dan peserta didik.

\section{B. PEMBAHASAN}

\section{Kemampuan Komunikasi Matematis}

Pembelajaran adalah proses komunikasi fungsional antara siswa dengan guru dan siswa dengan siswa, dalam rangka perubahan sikap dan pola pikir yang akan menjadi kebiasaan bagi siswa yang bersangkutan. Guru berperan sebagai 
komunikator, siswa sebagai komunikan, dan materi yang dikomunikasikan berisi pesan berupa ilmu pengetahuan. Dalam komunikasi banyak arah dalam pembelajaran, peran-peran tersebut bisa berubah, yaitu antara guru dengan siswa dan sebaliknya, serta antara siswa dengan siswa (Suherman, 2001).

Komunikasi adalah proses menuangkan ide atau gagasan dan pemahaman matematis menggunakan angka, gambar, dan kata, dalam beragam komunitas termasuk didalamnya guru, teman sebaya, kelompok, atau kelas. Hal ini diungkapkan juga oleh Suryadi (2008) bahwa " Komunikasi matematika adalah cara untuk berbagi ide dan memperjelas pemahaman pada belajar matematika". Menurut NCTM (2000) dalam komunikasi matematika, ide datang dari proses pemecahan masalah menjadi objek refleksi, perbaikan, diskusi, dan perubahannya . Ketika siswa ditantang untuk memecahkan masalah, mereka akan memiliki kesempatan untuk memikirkan dan mencoba menyelesaikannya. Takahashi (Suryadi, 2008) mengatakan bahwa kesulitan siswa untuk memecahkan masalah, ide-ide yang berbeda, dan solusi yang berbeda merupakan sumber daya potensial yang mendorong siswa untuk berbagi, membandingkan, membenarkan, menjelaskan, atau membahas masalah tersebut. Interaksi antara siswa selama seluruh kegiatan kelas memberikan kesempatan untuk mengembangkan kemampuan matematika mereka termasuk pemahaman konseptual dan prosedural. Interaksi siswa di mana ide-ide matematika dieksplorasi dari titik pandangan yang berbeda bisa membantu siswa untuk memperdalam pemahaman mereka, dan mengembangkan kemampuan mereka untuk berkomunikasi, menjelaskan, membenarkan, dan mendiskusikan ide-ide matematika.

Isoda ( dalam Ulep, 2010) mengatakan bahwa Guru yang ideal menolong siswanya untuk belajar dengan tidak mengutamakan jawaban tetapi bagaimana merefleksinya, karakterisasi, dan mendiskusikan masalah, serta bagaimana mereka berinisiatif sendiri, membentuk atau menemukan jawaban yang valid. Dalam hal ini siswa dituntut untuk melakukan investigasi dimana mereka memformulasikan masalah, merencanakan penyelesaian dan interpretasi informasi, menyimpulkan jawaban, mengkomunikasikan apa yang telah mereka pelajari, dan memformulasikan perluasan masalah. Jadi dalam hal ini kemampuan komunikasi matematis merupakan hal yang penting yang harus dimiliki siswa. Isoda selanjutnya mengusulkan beberapa komponen komunikasi matematis, yaitu:

a. Menggunakan bahasa yang tepat untuk mempromosikan pemahaman konseptual dan diskursus.

b. Menekankan penalaran logis.

c. Membedakan antara penjelasan konseptual dan deskripsi prosedural.

d. Membuat representasi yang bermakna.

e. Menumbuhkan simpati.

Pentingnya komunikasi matematik tercantum dalam tujuan pembelajaran matematika yang dituangkan dalam standar kompetensi mata pelajaran matematika sebagai berikut:

a. Melatih cara berpikir dan bernalar dalam menarik kesimpulan, misalnya melalui kegiatan penyelidikan, eksplorasi, eksperimen, menunjukkan kesamaan, perbedaan, konsistensi dan inkonsistensi. 
b. Mengembangkan aktivitas kreatif yang melibatkan imajinasi, intuisi, dan penemuan dengan mengembangkan pemikiran divergen, orisinil, rasa ingin tahu, membuat prediksi dan dugaan, serta mencoba-coba.

c. Mengembangkan kemampuan memecahkan masalah.

d. Mengembangkan kemampuan menyampaikan informasi atau mengkomunikasikan gagasan antara lain melalui pembicaraan lisan, grafik, peta, diagram, dalam menjelaskan gagasan.

Prinsip-prinsip dan Standar NCTM (2000) menyoroti juga pentingnya komunikasi sebagai bagian penting dari matematika dan pendidikan matematika. Melalui komunikasi sebuah ide menjadi objek refleksi, perbaikan, diskusi dan perubahan, dan inilah proses yang membantu membangun makna dan menetapkan ide-ide, serta menjadikan ide tersebut berlaku umum. Penekanan pentingnya komunikasi dalam matematika, dituangkan pula pada kurikulum 2013. Rumusan kompetensi sikap, pengetahuan, dan keterampilan yang dipergunakan dalam kurikulum 2013 mengedepankan pentingnya kreativitas dan komunikasi.

Pentingnya Komunikasi diungkapkan pula oleh Ahmad, Salim, dan Zainudin (2008) bahwa Komunikasi intrapersonal dan interpersonal sangat penting dalam pemecahan masalah. Mereka mempengaruhi proses kognitif dari pemecah masalah dan membantu mereka merenungkan tugas mereka untuk menemukan solusi terhadap masalah yang diberikan.

Craven (2000) memberikan dukungannya untuk menekankan pada komunikasi matematika siswa, memberikan ide-ide untuk merekam dan berbagi pembelajaran (misalnya, jurnal, laporan, poster, surat, cerita, model tiga-dimensi, sketsa/gambar dengan penjelasan, presentasi oral). Dia menyimpulkan dengan menyatakan bahwa siswa harus merasa bebas untuk mengeksplorasi, berbicara, membuat, dan menulis tentang matematika di lingkungan kelas yang menghormati keindahan dan pentingnya subjek. Siswa harus diberdayakan untuk mengambil resiko dan didorong untuk menjelaskan pemikiran mereka. Guru harus membangun tugas yang akan menghasilkan diskusi dan memberikan kesempatan bagi siswa untuk menjelaskan pemahaman konsep matematika mereka melalui gambar, kata, dan angka. Dengan cara ini, anak bisa menjadi mahir dan mengartikulasikan dalam mengkomunikasikan ide-ide matematika.

\section{Peran Guru dalam Meningkatkan Kemampuan Komunikasi Matematis.}

Peran guru sebagai ujung tombak keberhasilan dalam pelaksanaan kurikulum, memegang peran yang sangat penting demi ketercapaian tujuan yang diharapkan. Dalam pembelajaran matematika, seorang guru selain dituntut harus memiliki pengetahuan yang luas, dapat menciptakan suasana pembelajaran yang tidak monoton dan membosankan, mereka juga harus memiliki keinginan yang kuat untuk mengembangkan kemampuan berpikir siswa. Guru harus memberikan peluang bagi siswa untuk mengembangkan kemampuan- kemampuan ini, salah satu diantaranya yaitu dengan memberikan tugas-tugas matematika yang kaya, seperti diungkapkan NCTM (2000) bahwa tugas-tugas matematika yang kaya adalah faktor kunci dalam ruang kelas yang memiliki komunikasi sebagai tujuan utama. 
Adapun indikator-indikator kemampuan komunikasi matematis yang dapat dikembangkan (Sumarmo, 2012), yaitu:

a. Menyatakan suatu situasi, gambar, diagram, atau benda nyata ke dalam bahasa, simbol, idea, atau model matematik.

b. Menjelaskan idea, situasi, dan relasi matematika secara lisan atau tulisan

c. Mendengarkan, berdiskusi, dan menulis tentang matematika.

d. Membaca dengan pemahaman suatu representasi matematika tertulis.

e. Mengungkapkan kembali suatu uraian atau paragrap matematika dalam bahasa sendiri.

Berikut adalah beberapa contoh tugas matematika yang dapat mengembangkan kemampuan komunikasi matematis siswa, diantaranya:

a. Indikator kemampuan komunikasi matematis:

Menjelaskan idea, situasi, dan relasi matematika secara lisan atau tulisan.

Contoh:

Ada dua buah persegi yaitu persegi A dan persegi B. Persegi A panjang sisinya $4 \mathrm{~cm}$, dan persegi $\mathrm{B}$ panjang sisinya $1 / 2$ dari panjang sisi persegi $\mathrm{B}$. Jika persegi A dipotong menjadi dua bagian yang sama, samakah luas $1 / 2$ persegi A dengan luas persegi B? Berikan penjelasan yang mendasari jawabanmu.

b. Indikator kemampuan komunikasi matematis::

Menyatakan suatu situasi, gambar, diagram, atau benda nyata ke dalam bahasa, simbol, idea, atau model matematik.

Contoh:

Langit-langit sebuah gedung berbentuk lingkaran dengan panjang diameternya 28 meter. Pak Andi adalah salah satu pengurus gedung itu, ia ditugaskan untuk mengecat permukaan langit-langit tersebut. Setiap $\mathrm{m}^{2}$ permukaan langit-langit memerlukan $1 / 4 \mathrm{~kg}$ cat dan setiap satu kaleng cat berisi $1 \mathrm{~kg}$. Langkah apakah yang harus dilakukan Pak Andi supaya cat yang disediakan sesuai dengan kebutuhan?. Berapa kaleng cat yang harus ia sediakan?.

Masalah terbuka dan menantang yang berkaitan dengan pengetahuan awal siswa secara kondusif bisa dilakukan melalui diskusi karena dengan diskusi siswa didorong untuk berpikir secara kolaboratif. Guru perlu diyakinkan bahwa tugas dengan berbagai tingkat akses akan memungkinkan siswa dengan tingkat latar belakang pengetahuan dan kemampuan matematika yang berbeda untuk bekerja pada masalah. Selain itu, ketika mereka bergerak melalui proses solusi, kolaborasi antara siswa akan timbul kesesuaian untuk berbagi pemahaman mereka sendiri dan menegosiasikan makna.

\section{PENUTUP}

Kemampuan berpikir matematis perlu dikembangkan oleh segala kalangan, baik guru, praktisi, ataupun peneliti. Telah banyak penelitian-penelitian yang mengembangkan kemampuan berfikir matematis tersebut, akan tetapi hal ini tidak menutup kemungkinan untuk selalu dikembangkan lebih lanjut. Prinsip umum yang harus diperhatikan adalah bahwa manusia tidak hanya sebagai individu kognitif, 
tetapi juga sosial yang memiliki keyakinan, emosi dan pandangan yang mempengaruhi perkembangan mereka sebagai peserta didik.

Melalui komunikasi, ide matematika dapat dieksploitasi dalam berbagai perspektif; cara berfikir siswa dapat dipertajam; pertumbuhan pemahaman dapat diukur; pemikiran siswa dapat dikonsolidasikan dan diorganisir; pengetahuan matematika dan pengembangan masalah siswa dapat ditingkatkan; dan komunikasi matematis dapat dibentuk sesuai dengan tingkatan atau jenjang pendidikan sehingga tingkat kemampuan komunikasi matematika menjadi beragam. Oleh karena itu komunikasi matematis sangat penting karena matematika tidak hanya menjadi alat berfikir yang membantu siswa untuk mengembangkan pola, menyelesaikan masalah dan menarik kesimpulan tetapi juga sebagai alat untuk mengomunikasikan pikiran, ide dan gagasan secara jelas, tepat dan singkat.

\section{DAFTAR PUSTAKA}

Ahmad,A., Salim,S.S., dan Zainuddin,R.(2008). A Cognitive Tool to Support Mathematical Communication in Fraction Word Problem Solving. ISSN: 1109-2750. Issue 4, Volume 7, April 2008. Tersedia. http://www.wseas.us/elibrary/transactions/computers/2008/25-472.pdf

Craven,S.(2000). "Encouraging Mathematics Communication in Children”. Ontario Mathematics Gazette, 38 (4), 25-27.

National Council of Teachers of Mathematics. (2000). Prinsiples and Standards for School Mathematics. Reston: NCTM.

National Council of Teachers of Mathematics. (2003). NCTM Program Standards. Programs for Initial Preparation of Mathematics Teachers. Standards for Secondary Mathematics Teachers.
[Online].
Tersedia: http://www.nctm.org/uploadedFiles/Math_Standards/ [ 10 Maret 2008].

Suherman, E. dkk. (2001). Strategi Pembelajaran Matematika Kontemporer. Bandung: Jurusan Pendidikan Matematika FPMIPA Universitas Pendidikan Indonesia.

Sumarmo,U.(2012). Pendidikan Karakter serta Pengembangan Berpikir dan Disposisi Matematik dalam pembelajaran Matematika. Makalah disajikan dalam Seminar Pendidikan Matematika di NTT tanggal 25 Februari 2012.

Suryadi,D. (2008). Critical Issues on Mathematical Communication: Lesson Learn from Lesson Study activities in Indonesia.Tersedia .http://file.upi.edu/Direktori/FPMIPA/JUR._PEND._MATEMATI KA/ 195802011984031 - DIDI_SURYADI/DIDI-08.pdf [2 Juni2012]

Ulep,S.A.(2010) Developing Mathematical Communication Philippine Classrooms. UP NISMED

Widjajanti, D.B., dan Wahyudin (2010). Mengembangkan Kemampuan Komunikasi Matematis Mahasiswa Calon Guru Matematika melalui Strategi Perkuliahan Kolaboratif Berbasis Masalah. Generated by Foxit PDF Creator (C) Foxit Software. Online. Tersedia. http://www.foxitsoftware.com [2 Juni 2012] 